\title{
Analysis Effect of Service Quality, Educational Facilities, and Method of Learning, Student Satisfaction and Loyalty to Students - Studies in the University of Widyatama Bandung
}

\author{
Yenny Maya Dora \\ Faculty of Business and Management, \\ University of Widyatama Bandung Indonesia
}

\begin{abstract}
This study aimed to analyze the effect of service quality, education facilities, and teaching methods in conjunction with student satisfaction and loyalty Widyatama University students. The research was conducted by survey method, the data obtained by distributing questionnaires to students. The study population was a student Of the Faculty of Business and Management, University of Widyatama. Data were analyzed using Structural Equation Modeling (SEM) with AMOS. From these results it can be concluded that the loyalty of the students affected by the quality of the service through student satisfaction. Loyalty affected by the Educational Facilities through student satisfaction. And loyalty is also influenced by learning through student satisfaction.
\end{abstract}

Keywords: Teaching Methode, Service Quality, Educational Facilities, Student Satisfaction, and Loyalty.

\section{Introduction}

\section{Backgrond}

Competing in an effort to provide services to customers intensifies, service units at the company beforehand only provide pickup services are now required to provide the best service to its customers. Service units capable of serving the needs and desires of customers well able to have competitiveness for the service business. Service used benchmarks as an effort to increase customer satisfaction to the company. Higher Education whose management is guided by the interest of the academic community, namely; Students, lecturers, and education personnel. It should have the completeness of various supporting facilities to support the achievement of the best service quality.

Almost all organizations are focused on high satisfaction because if the customers are just satisfied, then they are easy to change their mind when it gets a better offer. Those who are very satisfied are more difficult to change their choices. High satisfaction creates attachment to the company that will create a sense of loyalty to the company.

The creation of customer satisfaction can provide several benefits, including the relationship between businesses and customers into a harmonious, provide a good foundation for the repurchase and the creation of customer loyalty, as well as form a recommendation by word of mouth (word of mouth) that benefit the company (Tjiptono, 2005). A decision-making process not only ends with a purchase transaction, but is followed by the stage of post-sale behavior, (especially in broad decision-making). In this stage the consumer feels a certain level of satisfaction or dissatisfaction that will affect the next behavior. If the customer is satisfied, he or she will show a great opportunity to buy or buy another product in the same company in the future (Tjiptono, 2005).

According to Ratnasari and Aksa $(2011,177)$ the main factors affecting consumer satisfaction are service quality, price and product quality. Meanwhile, according lupiyoadi $(2011,168)$ one indicator in the service business is quality, where one way to create customer satisfaction is through quality improvement.

Customer satisfaction is a crucial factor in marketing, and customer disappointment in providing services can lead to future corporate destruction. Increasing the quantity of universities requires that each educational institution should pay attention 
to the quality of education and institutions so as to be able and excel in the competition. Efforts to meet the wishes of students and prospective students is the key to successfully win the competition (Simonson, 1993).

The best action a higher education institution needs is to use feedback from students or prospective students to control organizational change (Bergin, 1997). Correspondence between the desire or the perception of the consumer (customer voice) and the will of the college management organization (company voice) is an essential condition of success of higher education process (Muafi and Yuni Siswanti, 2007).

Asiabaka (2008) argues that facilities play an important role in the actualization of educational goals and objectives by meeting the physical and emotional needs of staff and students at school. A study conducted by Abbas, Malik, Chaudhry, and Imdadullah (2011).

This research is in the Faculty of Business and management of Widyatama University, because it wants to do empirical testing about how increasing the loyalty of students is influenced by the quality of service, educational facilities, learning methods and satisfaction. Another reason that is the basis of this research, namely; The number of students of the Faculty of Business and Management in the period 2015/2016 academic year at most of the number of other faculty students.

\section{Literature review}

\section{Service quality}

Quality is at the heart of the continuity of existence of an institution. Movement of the revolution in improving the quality of integrated into the needs as well as demands that can not be ignored if the institution wants to continue to exist and develop. Increasingly tight competition among educational institutions (Higher Education) increasingly demands a college to always pamper its customers (students) with good service, because students will look for colleges that provide the best service for him.

The quality of a college is determined by the quality of services provided, where quality services can be identified through customer satisfaction in this case is the student. For a college service satisfaction is more oriented to the student because the student is the primary customer of the college. Universities as a service industry should continue to think about the importance of customer service more maturely, because now it is increasingly realized that customer satisfaction and satisfaction is a vital aspect in order to stay in business and win the competition (Tjiptono, 2004: 145).

Quality service will give students satisfaction. Student satisfaction is aimed at the existence of student loyalty in college and students will tell about satisfactory academic service to others.

According to Tilaar (2002: 11) today, high education is faced with demands for quality and accountability for the educational services that he provides, so quality services must be provided to satisfy his customers. Parasuraman, Zeithaml, and Berry (1985: 41) define service quality as a discrete, but not equal to satisfaction, as a result of the comparison between expectations and performance.Based on this definition, it is expected that the quality of good and professional services will arise customer satisfaction.

The concept of service quality is very popular is the concept of SerQual developed by Parasuraman, Berry and Zeithml (1988: 16). The first time the concept of service quality dimensions is formulated into ten dimensions, then simplified into five dimensions:

1. Tangible (direct evidence) includes physical facilities, equipment, employees, and means of communication;

2. Reliability (reliability), ie the ability to provide promptly, accurately, and satisfactorily promised services;

3. responsiveness (responsiveness), namely the desire of staff to help customers and provide service with a response mem; 4. Assurance, including the knowledge, competence, courtesy, and confident nature of the staff, free from harm, risk, or doubt; and

5. Empathy (empathy), including the ease of establishing relationships, good communication, personal attention, and understanding of the individual needs of customers.

If the service provided meets the wishes, hopes, and needs of the student, it can be judged that the service is satisfactory, and vice versa, if the service provided can not meet the wishes, expectations, and needs of the student, it can be concluded that the service is not satisfactory. 


\section{Educational Facilities}

In a business engaged in services, then all existing facilities that condition facilities, completeness, interior design, and cleanliness of the facility should be considered especially that closely related to what is perceived or obtained by consumers directly. The facility itself is a physical resource that must exist before a service can be offered to consumers (Tjiptono, 2005). The facilities provided by service companies greatly influence consumer decisions, as they are closely related to the formation of customer perceptions. The closeness of the relationship can be seen from the tendency that appears in the product market today, where consumers have a desire for the product has a complete facility (Sutiono, 2000). Complete education facilities are required by the university to support the process of teaching and learning activities. Students will feel comfortable in studying when all the required facilities can be available in the vicinity.

Lovelock and Wright (in Rosita, 2009) states that physical evidence is visual or other tangible clues that provide evidence of service quality. Facilities play an important role for the university in assisting and supporting the process of student study activities. Students will feel comfortable if the facilities they need can be available in the surrounding environment.

Complete educational facilities will support the university in developing its good name. Dikarena comfort of facilities available, give effect and a good impression on the students, which ultimately generates word of mouth and will further influence the decision to choose to continue their studies at the university.

\section{Learning methods.}

According Widyartini, (2002), Teaching and learning process is a process of translating and transforming the values contained in the curriculum to students, through the interaction of teaching and learning in schools. The process of teaching and learning is technically an active interaction between faculty and students, where faculty manage the learning resources (including Herself) to provide a learning experience to students.

\section{Customer Satisfaction (Student)}

Student satisfaction will be achieved if there is a match between services provided to students. As expressed by Wadwa and Radja (2006: 222) that student satisfaction will be the service received from the conformity of expectations and performance of services received. Departing from the basic concept of customer satisfaction, college is basically a service industry that memeberikan service or educational services whose purpose is to memeberikan satisfaction on the customer (student).

Satisfaction according to Expert Day (Tjiptono, 2004: 146) states that satisfaction or dissatisfaction is the customer's response to the evaluation of discrepancy / disconfirmation that is felt between the previous expectations and the actual performance of products perceived after use. The level of student satisfaction on education services can be known by comparing anatara expectations with the reality that students feel.

Student satisfaction becomes very important because it will result in a loyal attitude to college, willing to promote the institution to others, increase public interest to continue the education at the college, increase the bargaining position of the college, and increase the image of the college. In addition, students will also promote good services from universities to other prospective students so that will increase the number of students who study at the college.

Included in student satisfaction include curriculum in accordance with student expectations, the design of lectures in accordance with student expectations, presentation of materials and evaluation in accordance with student expectations, facilities and lecture infrastructure in accordance with the expectations of students, laboratories that match the expectations of students, and mentoring Which is in line with student expectations. Student satisfaction is a mission that must be realized if an educational institution wants to be accepted by the community and can continue to exist and develop in the midst of community support. Forms of service received by students in universities may include services of academic, student and administrative activities.

\section{Customer loyalty}

According to Griffin (2005), "The definition of loyalty is the formation of attitudes and behavior patterns of a consumer to the purchase and use of products from their previous experience". Meanwhile, according to Engel, Blackwell, Miniard (in 
Hasan, 2008) suggests that, "Customer loyalty is a habit of repetitive behavior of purchases, linkage and high involvement in choice, and bericisi with external information search and alternative evaluation.

\section{Framework for Research Thinking and Hypotheses}

In Figure 1, the following framework is presented.

\section{Figure 1.}

\section{Research Framework}

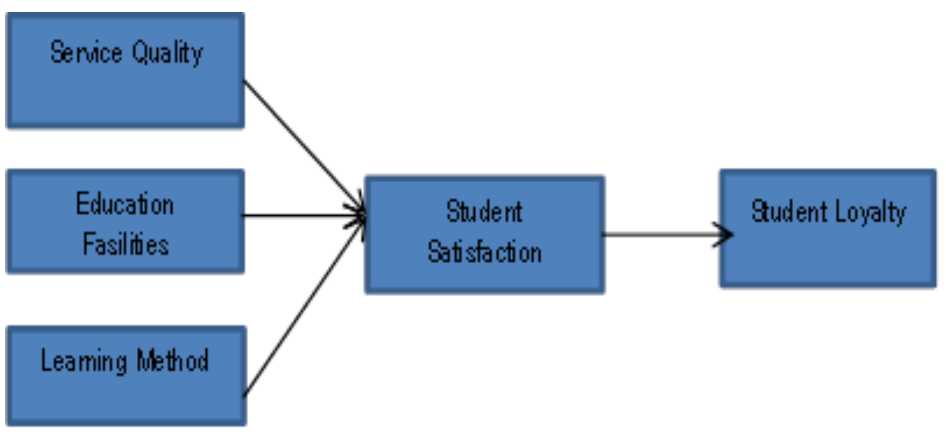

Based on the framework in Figure 1, the research hypothesis as follows:

1. H 1: There is a positive influence between the Quality of Service to the Student Satisfaction.

2. $\mathrm{H}$ 2: There is a positive influence among their Education Facilities Student Satisfaction.

3. $\mathrm{H}$ 3: There is a positive influence between Learning Method on Student Satisfaction

4. H4: There is a positive influence between Student Satisfaction with Student Loyalty.

\section{Research methods}

\section{Research variable}

The research variables can be grouped into two: first, exogenous variable (free) is Quality of Service (X1), Educational Facilities (X2), and Learning Method (X3). Second, the endogenous variables consisting of satisfaction ( $Y 1$ ) and loyalty (Y 2) (the dependent variable).

\section{Population and Sample}

In this study, the population is a student of Faculty of Business and Management of University of Widaytaama which is still active Academic Year 2015/2016 which amounted to 3,372 students. Of the population of 3.3.72 students, but researchers only take some of the population as research subjects (Sekaran, 2006). While Size of sampling in this research used slovin formula (Husein, 2008).

$$
\begin{aligned}
\mathrm{n} & =\frac{\mathrm{N}}{1+\mathrm{Ne}^{2}} \\
\mathrm{n} & =\frac{3.372}{1+3372 \times(0.05)^{2}} \\
\mathrm{n} & =358
\end{aligned}
$$




\section{Note :}

$\mathrm{N}=$ Number of samples

$\mathrm{N}=$ Population size

$E=$ Percentage of inaccuracy loosity due to sample error that can still be tolerated. The percentage of uncertainty allowance used in the study is $5 \%$.

Based on the calculation, the sample in this study as many as 358 students.

The sampling method with certain criteria (purposive sampling), the sampling is done by taking people who are elected according to the specific characteristics possessed by the sample. Researchers used a purposive sample because researchers used a student with specific criteria to be sampled. The criteria are the minimum students are in semester 4 , and the student is aged between 20 years to 25 years.

\section{Method of collecting data}

The data were collected by using questionnaires, ie a list of questions that were distributed to be filled in and returned or could also be answered under the supervision of the researcher.

\section{Data analysis method}

Analysis of the data in this study using structural equation model (SEM). According to Ferdinand (2006), the modeling of the complete SEM basically consists of measurement models and structural models. Measurement model or measurement model is intended to confirm a dimension or factor based on empirical indicators. Structural model is a model of the structure of the relationships that form or explain causality between factors.

\section{Results and Discussion}

\section{Test Instruments}

Test the Validity of Quality Service Questionnaire based on the calculation of validity test of learning variables, the results are presented

\section{Table 1}

\section{Test Results Quality of service}

\begin{tabular}{|l|l|l|l|}
\hline Item & Corrected Item- Total Correlation & R-table & Status \\
\hline Kual p 1 & 0.468 & 0.264 & Valid \\
\hline Kualp 2 & 0.649 & 0.264 & Valid \\
\hline Kualp 3 & 0.738 & 0.264 & Valid \\
\hline Kualp 4 & 0.598 & 0.264 & Valid \\
\hline Kualp 5 & 0.597 & 0.264 & Valid \\
\hline
\end{tabular}

Source: Primary data processed, 2017

According to the table 1 , it can be seen that the whole question of quality of service has a valid status, because the corrected item-total correlation $>0.264$ then the item / service quality entirely valid question.

Test of the Validity of Education Facility Questionnaire

Based on the test of the validity of the variable of satisfaction, the results are presented in table 2 .

\section{Table 2}


Test Results of Education Facilities Validity

\begin{tabular}{|l|l|l|l|}
\hline Item & $\begin{array}{l}\text { Corrected Item- } \\
\text { Total Correlation }\end{array}$ & R-table & Status \\
\hline Fas 1 & 0.330 & 0.264 & Valid \\
\hline Fas 2 & 0.451 & 0.264 & Valid \\
\hline Fas 3 & 0.502 & 0.264 & Valid \\
\hline
\end{tabular}

Source: Primary data processed, 2017

Based on Table 2, it can be seen that the whole question of Pemdidikan facilities have valid status, because the corrected item-total correlation $>0.264$ then the item / question entirely valid learning.

Test the Validity of Learning Method Questionnaire

Based on the calculation of validity test of Learning Method, the results are presented in table 3.

\section{Table 3}

\section{Test Result Validity of Learning Method}

\begin{tabular}{|l|l|l|l|}
\hline Item & $\begin{array}{l}\text { Corrected Item- } \\
\text { Total Correlation }\end{array}$ & R-table & Status \\
\hline M Pemb 1 & 0.336 & 0.264 & Valid \\
\hline M Pemb 2 & 0.462 & 0.264 & Valid \\
\hline M Pemb 3 & 0.320 & 0.264 & Valid \\
\hline M Pemb 4 & 0.451 & 0.264 & Valid \\
\hline M Pemb 5 & 0.512 & 0.264 & Valid \\
\hline
\end{tabular}

Source: Primary data processed, 2017

Based on Table 3, it can be seen that the whole question for Learning Method has a valid status, because the corrected item-total correlation $>0.264$ then the item / question entirely valid satisfaction.

Test the Validity of Student Satisfaction Questionnaire

Based on the calculation of validity test of Student Satisfaction is as follows.

\section{Table 4}

\section{Test Results of Student Satisfaction Validity}

\begin{tabular}{|l|l|l|l|}
\hline tem & $\begin{array}{l}\text { Corrected Item- } \\
\text { Total Correlation }\end{array}$ & R-table & Status \\
\hline Kepum 1 & 0.346 & 0.264 & Valid \\
\hline Kepum 2 & 0.462 & 0.264 & Valid \\
\hline Kepum 3 & 0.310 & 0.264 & Valid \\
\hline
\end{tabular}




\begin{tabular}{|l|l|l|l|}
\hline Kepum 4 & 0.442 & 0.264 & Valid \\
\hline Kepum 5 & 0.501 & 0.264 & Valid \\
\hline
\end{tabular}

Source: Primary data processed, 2017

Based on Table 4, it can be seen that the whole question for Student Satisfaction has a valid status, because the corrected item-total correlation> 0.264 then the item / question entirely valid Student Satisfaction.

Test the Validity of Student Loyalty Questionnaire

Based on the calculation of validity test of Student Loyalty is as follows.

\section{Table 5}

\section{Test Results of Student Loyalty Validity}

\begin{tabular}{|l|l|l|l|}
\hline Item & $\begin{array}{l}\text { Corrected Item- } \\
\text { Total Correlation }\end{array}$ & R-table & Status \\
\hline Loym 1 & 0.355 & 0.264 & Valid \\
\hline Loym 2 & 0.471 & 0.264 & Valid \\
\hline Loym3 & 0.302 & 0.264 & Valid \\
\hline Loym 4 & 0.452 & 0.264 & Valid \\
\hline Loym 5 & 0.502 & 0.264 & Valid \\
\hline
\end{tabular}

Source: Primary data processed, 2017

Based on Table 5, it can be seen that the whole question of loyalty Students have a valid status, because the corrected item-total correlation> 0.264 then the item / Student Loyalty entirely valid question.

\section{Test Reliability}

The instrument reliability coefficient is intended to see the consistency of answers to the statement items given by the respondent. As a tool of analysis using the method split (split half) by correlating total score of odd opponent is even, then calculated using the formula Cronbach alpha reliability '.

\section{Table 6}

\section{Reliability Test Results}

\begin{tabular}{|l|l|l|l|l|}
\hline No & Variable & Ralpha & Rkritis & Status \\
\hline 1 & Service quality & 0.660 & 0.600 & Reliable \\
\hline 2 & Education Faculties & 0.815 & 0.600 & Reliable \\
\hline 3 & Learning methods & 0.814 & 0.600 & Reliable \\
\hline 4 & Student Satisfaction & 0.826 & 0.600 & Reliable \\
\hline 5 & Student Loyalty & 0.813 & 0.600 & Reliable \\
\hline
\end{tabular}

Source: Primary data processed, 2017 
So the outcome of instrument reliability coefficient of Quality of Service, Educational Facilities, Learning Method, Satisfaction and Loyalty of students turned out to have a Ipha Cronbach values greater than 0.600 , which means that the five instruments otherwise reliable or meet the requirements.

\section{Analysis of Structural Equation Modeling (SEM)}

The results of the data analysis with structural equation method (structural equation modeling) or SEM, is presented in Table 7.

\section{Table 7}

\section{Feasibility Test Result Model Structural Equation Model (SEM)}

\begin{tabular}{|l|l|l|l|}
\hline Criteria & Cut-Off-Value & Analysis results & Model Evaluation \\
\hline c 2 (chi-square) & Expected small & 118,986 & Good \\
\hline Probability & $\geq 0.05$ & 0.266 & Good \\
\hline RMSEA & $\leq 0.08$ & 0.019 & Good \\
\hline CMIN / DF & $\geq 2.00$ & 1.048 & Good \\
\hline GFI & $\geq 0.90$ & 0.916 & Good \\
\hline AGFI & $\geq 0.90$ & 0.890 & Marginal \\
\hline TLI & $\geq 0.95$ & 0.998 & Good \\
\hline CFI & $\geq 0.95$ & 0.997 & Good \\
\hline
\end{tabular}

Source: Primary data processed, 2017

The results indicate that the model used is acceptable. Measurement indexes of TLI, CFI, CMIN / DF and RMSEA are within the expected value range even though AGFI is received marginally. Thus the feasibility test of the SEM model has met the acceptance requirements.

\section{Table 8}

\section{Testing Data Normality}

\begin{tabular}{|l|l|l|l|l|l|l|}
\hline Variable & Min & Max & Skew & Cr & Kurtosis & Cr \\
\hline LOY M4 & 1,000 & 5,000 & $-0,441$ & $-3,421$ & 0.648 & $-2,556$ \\
\hline LOY M3 & 2,000 & 5,000 & -0.212 & $-1,668$ & 0.106 & 0.423 \\
\hline LOY M2 & 2,000 & 5,000 & -0.126 & -0.992 & $-0,058$ & $-0,233$ \\
\hline LOY M1 & 1,000 & 5,000 & -0.277 & -2.198 & 0.297 & 1,171 \\
\hline KEP UM5 & 1,000 & 5,000 & -0.236 & $-1,879$ & -0.186 & -0.741 \\
\hline KEP UM4 & 1,000 & 5,000 & -0.395 & -3.103 & -0.091 & -0.354 \\
\hline KEP UM3 & 1,000 & 5,000 & -0.186 & $-1,478$ & $-0,246$ & -0.970 \\
\hline KEP UM2 & 1,000 & 5,000 & -0.168 & $-1,322$ & -0.528 & -2.093 \\
\hline KEP UM1 & 1,000 & 5,000 & -0.161 & $-1,278$ & $-0,601$ & $-2,378$ \\
\hline Kual P5 & 1,000 & 5,000 & -0.237 & $-1,867$ & -0.008 & -0.034 \\
\hline Kual P4 & 2,000 & 5,000 & -0.366 & $-2,886$ & 0.142 & 0.558 \\
\hline Kual P3 & 2,000 & 5,000 & -0.014 & -0.117 & -0.345 & $-1,367$ \\
\hline Kual P2 & 1,000 & 5,000 & -0.201 & $-1,578$ & -0.296 & $-1,163$ \\
\hline Kual P1 & 2,000 & 5,000 & -0.591 & $-4,677$ & 0.413 & 1.636 \\
\hline FAS3 & 1,000 & 5,000 & -0.137 & -1.018 & -0.697 & $-2,563$ \\
\hline FAS2 & 1,000 & 5,000 & -0.583 & -4.676 & 0,402 & 1.578 \\
\hline FAS1 & 2,000 & 5,000 & -0.902 & -6.335 & 0.766 & -3.101 \\
\hline M PEMB5 & 1,000 & 5,000 & -0.128 & -1.004 & -0.702 & $-2,770$ \\
\hline M PEMB4 & 1,000 & 5,000 & -0.591 & $-4,686$ & 0.373 & 1,479 \\
\hline
\end{tabular}




\begin{tabular}{|l|l|l|l|l|l|l|}
\hline M PEMB3 & 1,000 & 5,000 & -0.904 & $-7,135$ & 0.784 & $-3,090$ \\
\hline M PEMB2 & 2,000 & 5,000 & -0.378 & $-2,978$ & -0.086 & -0.343 \\
\hline M PEMB1 & 1,000 & 5,000 & -0.737 & $-5,839$ & 0.620 & 2,455 \\
\hline Multivariate & & & & & 14,013 & 1.773 \\
\hline
\end{tabular}

Source: Primary data processed, 2017

Evaluation is done by using the criteria of normality ratioskewness critical value and the kurtosis value, where the value of the ratio has a value smaller than the absolute value of 2.58 , meaning that data is normally distributed. From the data processing are shown in table 8 shown that there is no CR values for skewness which is outside the range of \pm 2.58 . Thus, the research data used has met the requirements of data normality, or it can be said that the research data has been normally distributed.

\section{Evaluation of multicollinearity and singularity}

The next test data is to see if there is multicollinearity and singularity in a combination of variables. Indication of multicolinearity and singularity can be known through the determinant value of the covariance matrix which is really small, or close to zero. From the data processing sample covariance matrix, determinant value is the determinant of the sample covariance matrix $=0.005>0$.

From the results of data processing can be known determinant of the value of the sample covariance matrix is far from zero. Thus, it can be said that the research data used there is no multicollinearity and singularity.

\section{Hypothesis testing}

After all assumptions can be met, then will be tested hypothesis as proposed in the previous chapter. To test the proposed hypothesis, it is done by analyzing the regression weights for each of its exogenous constructs against its endogenous constructs. By looking at $C R$ value which is identical with $t$-count, on processing result compared with critical value that is $\pm 1,96$ at level of significance $0,05(5 \%)$. The results of hypothesis testing are presented in table 9 .

\section{Table 9}

\section{Regression Weight Structural Equational Model}

\begin{tabular}{|l|l|l|l|l|}
\hline Relationship between Variables & Estimate & SE & CR & $P$-val \\
\hline Quality of service $(\mathrm{X} 1)==>$ Satisfaction $(\mathrm{Y} 1)$ & 0,312 & 0.106 & 2,929 & .003 \\
\hline Education facilities $(\mathrm{X}$ 2) ==> Satisfaction (Y 1) & 0.423 & 0.101 & 3,567 & 0,000 \\
\hline Learning Method $(\mathrm{X}$ ) ==> Satisfaction (Y 1) & 0.425 & 0.102 & 4,472 & 0.000 \\
\hline Satisfaction (Y 1) ==> Loyalty (Y 2) & .494 & 0.090 & 5,495 & 0,000 \\
\hline
\end{tabular}

Source: Primary data processed, 2017

From the test results in table 9 , it is found that all CR values are above 1.96 or with probabilities smaller than 0.05 . Thus all hypotheses are accepted.

\section{First Hypothesis Testing: Quality of Service positive effect on satisfaction.}

The results of the test of the estimation parameter coefficient for the test of influence which is the relationship between two hypothesized variables (learning with satisfaction) shows the value of estimation parameter coefficient of 0.312 and CR value 2.929 with probability 0.003 . This means there is a positive influence of Quality of Service on satisfaction.

\section{Second Hypothesis Testing: Educational Facility positive effect on satisfaction.}

The result of the test to the estimation parameter coefficient for the influence test which is the relationship between two hypothesized variables (educational facility with satisfaction) shows the value of estimated parameter coefficient 0,423 and CR value 3,567 with probability 0.000 . This means there is a positive influence of education facilities on satisfaction.

3. Third Hypothesis Testing: Methods of Learning positive effect on satisfaction. 
The test result of the estimation parameter coefficient for the influence test which is the relationship between two hypothesized variables (learning method with satisfaction) shows the value of estimation parameter coefficient of 0,425 and $C R$ value 4,472 with probability 0.000 . This means there is a positive influence of learning methods on satisfaction.

4. Fourth Hypothesis Testing: Satisfaction positive effect on loyalty.

The result of test to the estimation parameter coefficient for the influence test which is the relationship between two hypothesized variables (satisfaction with loyalty) shows the value of estimated parameter coefficient of 0.494 and CR value of 5,495 with probability 0.000 . This means there is a positive effect of satisfaction on loyalty.

\section{Discussion}

\section{Analysis of Service Quality Influence Against Satisfaction}

The result of the research shows that there is significant and positive influence of service quality to satisfaction. This suggests that increased quality of service will have an impact on increasing satisfaction. So the results of this study in accordance with the study Alma, Buchari (2007), Andini (2010), and Nahan (2013) which indicates that the quality of service influence on satisfaction.

\section{Analysis of the Effect of Education Facilities on Satisfaction}

The results of the study indicate that there is a significant and positive influence of education facilities on satisfaction. This means the improvement of educational facilities will increase student satisfaction. The results of research are in accordance with Andini's research (2010) which shows that educational facilities have an effect on satisfaction.

\section{Analiasa Effect of Learning Methods on Satisfaction}

The result of the research shows that there are significant and positive influence of learning method to satisfaction. This means increased learning will increase satisfaction. The results are in accordance with the research by Guolla which proves that the learning method is strongly related to the satisfaction of the lesson and the enthusiasm of the instructor is strongly related to the instructor's satisfaction (Guolla, 1999).

\section{Analysis of the Influence of Satisfaction Against Loyalty}

The results showed there was a significant and positive influence of satisfaction on loyalty. This means increased satisfaction will increase loyalty. The results of research strengthen research studies Sugandi (2003) which states consumer satisfaction has the greatest influence on consumer loyalty.

\section{Summary}

From the results of this study can be concluded that student loyalty can be built from Quality Service through Student Satisfaction, Education Facilities through Student Satisfaction, and Learning Methods through Student Satisfaction. The result of the hypothesis test of the study gives the following conclusion:

1. There is a positive influence between the variable quality of service to student satisfaction. Thus, the quality of service has a positive effect on student satisfaction. Variable quality of service use indicators tangibles, reliability, responsiveness, assurance, and empathy. The results of this study strengthen research from Sutino and Sumarno (2005), Margaretha (2004), Agustiono and Sumarno (2006), Alma et al (2007), Samosir (2005),

Sutardji and Maulidyah (2006).

2.There is a positive influence between the Education Facility on student satisfaction. Thus means Education Facility have positive effect to student's satisfaction. Education Facility uses indicator of condition of physical facility, lecture building and supporting facility of lecturing. The results of this study strengthen the results of research from andini (2010) that educational facilities affect student satisfaction.

3. There is a positive influence between Learning Methods on student satisfaction. Thus means Learning Method positive effect on student satisfaction. The learning method uses indicators of knowledge, enthusiasm, learning media, communication, and guidance of student learning difficulties. The results of this study reinforce the opinion of Alma (2005, $100)$ that all existing value chains in educational institutions, should create added value for students. All personnel, as well 
as the educational process as the key value chain must be able to provide satisfaction in the service to the students. The results of this study also strengthen research from Michael Guolla (1999).

4. There is a positive influence between student satisfaction variable on student loyalty. Thus, student satisfaction has a positive effect on student loyalty. Student satisfaction using indicator from research conducted by Sutardji and Maulidyah (2006). Indicators used for student satisfaction are service system, ease and speed of getting information, cost is not too expensive, and pass on time. The results of this study strengthen research conducted by Sutino and Sumarno (2005), Margaretha (2004), Dyah Sugandini (2003), Agustiono and Sumarno (2006), Buchari Alma et al (2007). As for student loyalty the indicator used is not moving students to other universities, recommending, having confidence and not affected by other universities.

\section{Bibliography}

[1] Andini, Nurul. 2010, Analysis of the Effect of Perception on Parents' Decisions Selecting Educational Services At SDIT Bina Insani Semarang ".

[2] Agustiono, Budi, and Sumarno 2006, "Analysis of the Effect of Service Quality Satisfaction and Loyalty Inpatient Hospital", Journal of explanation Vol. 1 No.1 April 2006.

[3] Alma, Buchari, Main, Rd. Dian H. Wibowo, Lili Adi, 2007, Analysis of the Elements of Dominant Service Quality; Relation to Customer Satisfaction and Loyalty (Case Taplus at PT. Bank BNI UPI), Anthology Strategic, Business Management based on the results of research, the First Matter, April 2007, Alfabeta, Bandung, p. 138 - 151.

[4] Alma, Buchari, 2005, Strategic Marketing Services Marketing, Second Matter, March 2005, Alfabeta, Bandung.

[5] Alma, Buchari, 2007, the Higher Education Services Marketing Strategy Anthology. Based Business Management Strategic Research, the First Matter,. April 2007, Bandung: Alfabeta.

[6] Engel, James F., Blackwell, Roger D., and Miniard., Paul W., 1995, Consumer Behavior, Sixth Edition, Volume II, Binarupa Literacy, Jakarta.

[7] Ferdinand, Augusty 2006, Structural Equation Modeling in PenelitianManajemen, Application Models for PenelitianMagister Complicated Research and Doctoral Dissertation, BP Diponegoro University, Semarang.

[8] Gundersen, MG, M. Heide, and UH Olsson, 1996, Hotel Guest Satisfaction among Business Travelers, Cornell HRA, Quarterly, 4: p. 72-80.

[9] Guolla, Michael, 1999, "Assessing the Teaching Quality Relationship to Student Satisfaction: Customer Satisfaction Applied Research in the Classroom", Journal of Marketing Theory and Practice, Summer, 1999; 7, 3; ABI / INFORM Global, University of Ottawa, p. 87-96.

[10] Kandampully, J and Suhartanto, D., 2000, "Customer Loyalty in the Hotel Industry: The Role of Customer Satisfaction and Image", International Journal of Contemporary Hospitality Management , p. 346-351.

[11] Kotler, Philip. Manajamen 2005. Marketing, Volume 1 and 2. Jakarta: PT. Index. Gramedia Group.

[12] Margaretha, Moureen 2004, "Study of Customer Loyalty in Group Insurance Division 1912 (Case Study in Central Java)",

[13] Parasuraman, A., Zeithaml, Valerie, and Berry, L., 1988, "Servqual: Multiple Item Scale for Measuring Consumer Perceptions of Service Quality", Journal of Retailing , Vol. 64, p.12 - 36.

[14] Sian, Posman 2004, Measuring the Quality of Higher Education, the Daily Voice Reform. (October 19, 2004).

[15] Rusdarti 2004, "The Effect of Service Quality and Value Service to Customer Loyalty in BPD Central Java Semarang Branch", Journal of Business Strategy , Vol. 13 / July / 2004, p. 54-65.

[16] Naidoo, Zurni Zahara, 2005, "The Effect of Service Quality on Student Satisfaction Using USU Library", Library: Journal of Library and Information Studies , Vol. 1, no. 1, June 2005, p. 28-36.

[17] Salomon, R. Michael and Stuart, Elnora W.. 2003. Marketing Real People, RealChoices, International Edition. Prentice Hall. New Jersey.

[18] Sugandini, Dyah 2003, "Antecedents of Consumer Loyalty in the Hospitality Industry (Studies in starred hotels in Yogyakarta)", Forum, Vol. 6, no. 2, August 2003, p. 181-200.

[19] Sugiyono 2004, Business Research Methods, Alfabeta, Bandung. 
[20] Sutardji, and Maulidyah, Sri ISMI 2006, "Analysis of Factors Influencing the Library User Satisfaction: A Case Study Library Crops Research Institute for Legumes and Tubers", Journal of Agricultural Library, Vol. 15, no. 2, 2006, p. 32-37.

[21] Sutino and Sumarno 2005, "The Effect of Product Quality (Services) and Quality of Service to the Customer Satisfaction and Customer Loyalty in PT.POS Indonesia Semarang 50000", Magazine of Scientific Kopertis Region VI , Vol. XV no. 23, April / May 2005, p. 9-20.

[22] Tjiptono, Fandy. 2000. Management of Services. Yogyakarta: Andi.

[23] Tjiptono, Fandy 2005, Marketing Strategy, Publisher Andi, Yogyakarta.

[24] Wibowo, Lili Adi, 2007, Effect of Product Quality, Service and Price terhadapKepuasan Computer Users in the Computer Laboratory of University in Bandung, Anthology Strategic , Business Management based on the results of the research, the First Matter, April 2007, Alfabeta, Bandung, p. 168-201.

[25] Widyaratna, Theresia, Danny, and Chandra, Filicia, 2001, "Analysis of Consumer Satisfaction and Loyalty to the level of sales at Warung Bu Kris (Case Study on Chicken Penyet as Warung Bu Kris, main menu)", Journal of Management and Entrepreneurship , Vol. 3, no. 2 September2001, p. 85-95.

[26] Widyartini 2002, Quality Management of Teaching and Learning, Knowledge, Attitude, Skills and Cognition Student Conduct Science Experiments on Elementary School Not Patronage Patronage and in the city of Semarang , Research Graduate Studies Program Management Education, State University of Semarang.

[27] Zeithaml, Valerie A; A Parasuraman; Leonardo L. Berry, 1988, "Servqual a Multiple-ltem Scale for Measuring Consumer Perception of Service Quality", Journal and Retailing, Vol. 64, Spring, p. 12-40.

[28] Zeithaml, Valerie, 1988, "Consumer Perceptions of Price, Quality, and Value: A Means-End Model and Synthesis of Evidence", Journal of Marketing , Vol. 52, July, p.2 - 22.

[29] Zurni Zahara Samosir. 2005. Effect of Service Quality on Student Satisfaction Using USU Library. Journal of Library and Information Studies, Vol. 1, No. 1, June 2005. 